\title{
Repurposing the anti-malarial drug, quinacrine: new anti-colitis properties
}

\author{
Alexander A. Chumanevich ${ }^{1}$, Erin E. Witalison ${ }^{1}$, Anusha Chaparala ${ }^{1}$, Anastasiya \\ Chumanevich ${ }^{1}$, Prakash Nagarkatti ${ }^{2}$, Mitzi Nagarkatti ${ }^{2}$ and Lorne J. Hofseth ${ }^{1}$ \\ ${ }^{1}$ Department of Drug Discovery and Biomedical Sciences, South Carolina College of Pharmacy, University of South Carolina, \\ Columbia, SC, USA \\ 2 School of Medicine, University of South Carolina, Columbia, SC, USA \\ Correspondence to: Lorne J. Hofseth, email: hofseth@sccp.sc.edu \\ Keywords: quinacrine, colitis, inflammation, dextran sulfate sodium, oxazolone \\ Received: June 08, $2016 \quad$ Accepted: June 15,2016 Published: July 14, 2016
}

\section{ABSTRACT}

Background: Ulcerative colitis (UC) is a chronic inflammatory bowel disease that is associated with an increased risk of colorectal cancer in 8-10 years after disease onset. Current colitis treatment strategies do not offer a cure for the disease, but only treat the symptoms with limited success and dangerous side-effects. Also, there is no preventive treatment for either UC or colorectal cancer. Quinacrine is an antimalarial drug with versatile use in the treatment of diseases involving inflammatory response such as rheumatoid arthritis and lupus erythematosus. It also has putative anti-cancer effect. Quinacrine's anti-inflammatory, anti-oxidant properties, and antitumorigenic properties make it a potential small molecule preventive agent for both UC and associated colorectal cancer.

Results: There were obvious changes in the CDI, histology, and inflammatory load in quinacrine-treated groups in a dose and time dependent manner in both models of UC, induced by chemical or haptenating agent.

Methods: We tested quinacrine at two different doses as a colitis treatment agent in two mouse models of UC - the dextran sulfate sodium and oxazolone. The clinical disease index (CDI), histological changes of the colon, levels of inflammatory markers (Cox-2, iNOS, p53) and overall health vitals were evaluated.

Conclusions: We demonstrate that quinacrine successfully suppresses colitis without any indication of toxicity or side-effects in two mouse models of UC.

\section{INTRODUCTION}

Ulcerative colitis (UC) is a chronic disease that causes inflammation and ulcers in the colon and the rectum. Colorectal cancer is the most serious complication of ulcerative colitis [1]. The risk of developing colorectal cancer increases after 8-10 years of colitis at a rate of $0.5-1 \%$ for every year of disease duration [2]. The severity of the disease also has a significant impact on the transformation of the disease into cancer [3]. Current medications only help in alleviating the symptoms, but for the most part results are modest and there are dangerous side effects.

Quinacrine (IUPAC name 4-N-(6-chloro-2methoxyacridin-9-yl)-1-N,1-N-diethylpentane-1,4- diamine), approved by the FDA, is a heterocyclic threering compound that was widely used during World War II as an anti-malarial agent. Over the last half century, it has been used for the treatment of giardiasis, tapeworm infestations, and connective tissue diseases, such as lupus erythematosus and rheumatoid arthritis [4-8]. Mechanistically, it is becoming increasingly apparent that quinacrine targets several key players involved in inflammation and the inflammation-to-cancer sequence [9]. For example, quinacrine activates p53 and superoxide dismutase, and inhibits NF- $\mathrm{BB}$ and phospholipase A2 [10-15]. Anti-cancer properties include the induction of apoptosis and cell cycle arrest in cancer cells [14-17], as well as the inhibition of Wnt-TCF signaling [18] and topoisomerase activity [19]. Quinacrine can also modify 
the expression of microRNAs involved in carcinogenesis [13].

Recognizing these anti-cancer and antiinflammatory properties of quinacrine, we hypothesized that quinacrine can suppress colitis in mice. In this article we test this hypothesis in two different mouse models: a DSS model, and Oxazolone model of colitis, showing a significant decrease in the overall colonic inflammatory load in the quinacrine treated animals.

\section{RESULTS}

\section{Quinacrine downregulates iNOS in murine macrophages cell line}

The cellular levels of nitric oxide (NO) and associated reactive nitrogen species (RNS) are driving factors of inflammation and cancers associated with chronic inflammation [20]. Since quinacrine has putative anti-inflammatory properties, we tested its ability to affect NO synthesis in vitro, using the ANA-1 murine macrophages cell line. Western blot analysis shows that pre-incubation of ANA-1 cells with quinacrine effectively attenuates the induction of iNOS for up to 24 hours (Figure 1A and 1B).

\section{Quinacrine stimulates inflammatory cell apoptosis}

We have previously shown that compounds that both: (a) suppress iNOS induction in inflammatory cells; and (b) induce apoptosis in inflammatory cells in vitro; are highly likely to suppress colitis in vivo. We have demonstrated this with Resveratrol, American Ginseng, a protein arginine deiminase inhibitor, Chlor-Amidine, and with a Hexane Fraction of American Ginseng [21-26]. Therefore, before testing the efficacy of quinacrine against colitis in vivo, we first asked whether quinacrine can induce apoptosis in inflammatory cells. Consistent with this understanding, Figure $1 \mathrm{C}$ and $1 \mathrm{D}$ show quinacrine induces apoptosis in ANA-1 mouse macrophages.

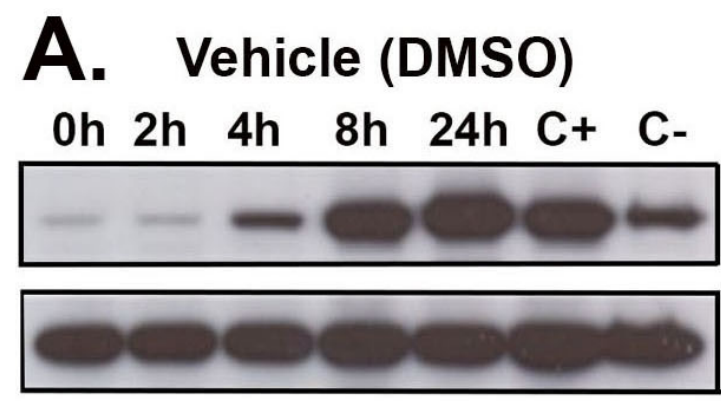

B. Quinacrine

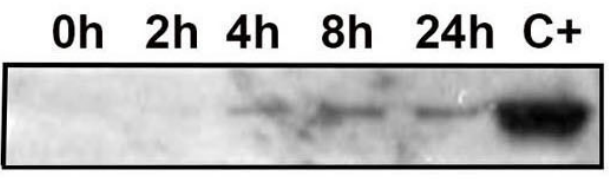

iNOS

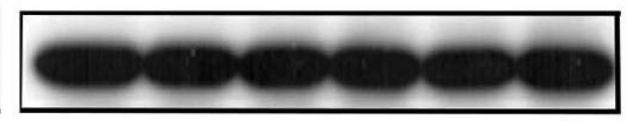

GAPDH

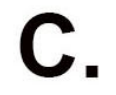

\section{Vehicle (DMSO)}

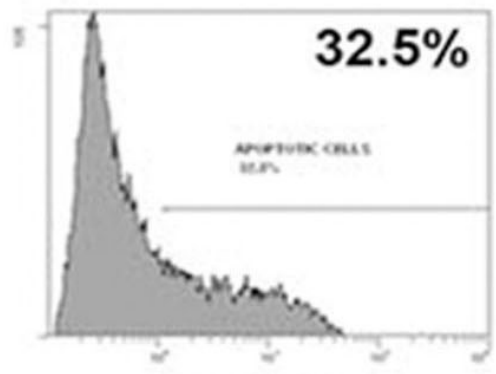

TUNEL
D. Quinacrine

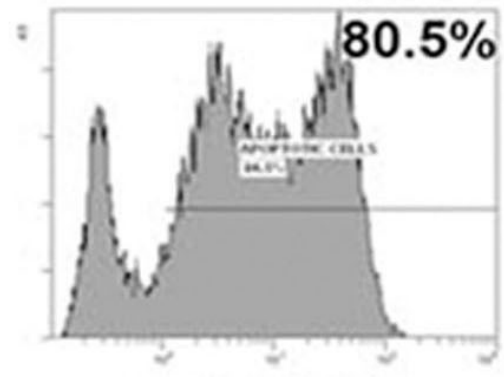

TUNEL

Figure 1: Quinacrine suppresses the activation of iNOS and induces apoptosis in vitro. ANA-1 mouse macrophages were pre-incubated for $12 \mathrm{~h}$ with $100 \mu \mathrm{g} / \mathrm{ml}$ of quinacrine B. or a vehicle (DMSO) A. Quinacrine was washed off, and then media containing $100 \mu \mathrm{g} / \mathrm{ml} \mathrm{IFN}-\gamma$ to stimulate cells were added. Following the indicated incubation time, cells were harvested for protein and examined for a response with iNOS being the inflammation marker. The positive control $(\mathrm{C}+$ ) is $A N A-1$ cells not exposed to quinacrine (on panel $\mathrm{B}$ ) or vehicle (on panel A) at $24 \mathrm{~h}$ time point. The negative control (C-) corresponds to the ANA-1 cells exposed to vehicle only at $24 \mathrm{~h}$ time point. GAPDH was probed for the background and loading control. For apoptosis C. D., TK6 lymphoblastoid cells were exposed to vehicle (DMSO) (C), or $100 \mathrm{ug} / \mathrm{ml}$ quinacrine (D) for $12 \mathrm{~h}$, then assessed for apoptosis by TUNEL labeling. 
Table 1: Gross characteristics of treated groups in DSS model.

\begin{tabular}{|c|c|c|c|c|c|c|}
\hline Treatment & $\begin{array}{l}\text { Weight } \\
\text { change, } g\end{array}$ & $\begin{array}{l}\text { Colon } \\
\text { Length, cm }\end{array}$ & CDI & Spleen, $\mathbf{m m}^{3}$ & $\begin{array}{l}\text { WBC Count, } \mathbf{m} / \\
\mathbf{m m}^{3 \dagger}\end{array}$ & $\begin{array}{l}\text { RBC Count, } \\
\text { b/mm } \mathbf{m m}^{3} \uparrow \dagger\end{array}$ \\
\hline Water & $1.6 \pm 0.0$ & $9.7 \pm 0.3$ & $0.2 \pm 0.1$ & $101.5 \pm 17.8$ & $7.4 \pm 0.4$ & $9.5 \pm 0.2$ \\
\hline $2 \%$ DSS (7 days) & $-0.4 \pm 0.5$ & $8.0 \pm 0.2$ & $5.5 \pm 0.9^{*}$ & $199.8 \pm 19.3$ & $8.9 \pm 0.5$ & $10.0 \pm 0.2$ \\
\hline $2 \%$ DSS (14 days) & $-2.1 \pm 0.5$ & $7.0 \pm 0.2$ & $6.3 \pm 0.1$ & $274.3 \pm 35.5$ & $10.6 \pm 0.5$ & $8.8 \pm 0.2$ \\
\hline $2 \%$ DSS (17 days) & $-2.6 \pm 0.69$ & $6.5 \pm 0.21$ & $8.9 \pm 0.1$ & $275.4 \pm 14.6$ & $8.6 \pm 0.5$ & $8.9 \pm 0.2$ \\
\hline $\begin{array}{l}2 \% \mathrm{DSS}+50 \mathrm{mg} / \mathrm{kg} \text { of } \\
\text { Quinacrine }(14 \text { days })\end{array}$ & $-0.6 \pm 0.6$ & $8.6 \pm 0.3$ & $4.2 \pm 0.3^{*}$ & $152.4 \pm 13.2$ & $9.5 \pm 0.6$ & $9.18 \pm 0.2$ \\
\hline $\begin{array}{l}2 \% \text { DSS }+50 \mathrm{mg} / \mathrm{kg} \text { of } \\
\text { Quinacrine }(17 \text { days })\end{array}$ & $-1.6 \pm 0.4$ & $8.2 \pm 0.3$ & $4.0 \pm 0.8^{*}$ & $162.7 \pm 27.1$ & $6.1 \pm 0.4$ & $9.3 \pm 0.4$ \\
\hline $\begin{array}{l}2 \% \mathrm{DSS}+10 \mathrm{mg} / \mathrm{kg} \text { of } \\
\text { Quinacrine }(14 \text { days })\end{array}$ & $-1.5 \pm 0.5$ & $8.4 \pm 0.3$ & $4.9 \pm 0.8^{*}$ & $163.9 \pm 9.7$ & $9.6 \pm 0.4$ & $8.57 \pm 0.2$ \\
\hline
\end{tabular}

Values are group averages $\pm \mathrm{SE}$. All values are significantly different from corresponding 2\% DSS only and Water groups. WBC, white blood cells. RBC, Red Blood Cells. $\dagger$ Millions per cubic milliliter of blood. $\dagger \dagger$ Billions per cubic milliliter of blood.

\section{Quinacrine suppresses colitis in DSS mouse model in both dose- and time- dependent manner}

$\mathrm{UC}$ is associated with long lasting inflammation in the bowels. Based on our in vitro studies where quinacrine suppresses iNOS induction and drives apoptosis of inflammatory cells, we have tested it on mice to check if it suppressed DSS induced colitis. Quinacrine was given to mice ad libitum at the two doses of $50 \mathrm{mg} / \mathrm{kg}$ and $10 \mathrm{mg} / \mathrm{kg}$ equivalent in the water after 1 week exposure to $2 \%$ DSS. The mice that received no quinacrine treatment showed moderate to severe inflammation and mild ulceration with a histology score rising gradually over the exposure time from $7.8 \pm 1.04$ at 7 days to $26.2 \pm 1.7$ at 14 days and to $27.11 \pm 1.6$ at 17 days time points. In contrast, although colitis did not return to that of the water-only treated group, the quinacrine-treated mice demonstrate mild inflammation and ulceration at both doses, as reflected by histology score of $16.5 \pm 3.0$ for the quinacrine dose of 10 $\mathrm{mg} / \mathrm{kg}$ and $13.1 \pm 2.6$ for the quinacrine dose of $50 \mathrm{mg} / \mathrm{kg}$ at the 14 day time point (Figure 3). Interestingly, further treatment with quinacrine at a dose of $50 \mathrm{mg} / \mathrm{kg}$ reduces inflammation score even more - to $9.9 \pm 2.2$ at 17 days time point. Multiple additional end points support this conclusion (Table 1). Since mouse colon length decreases in an inflamed state, we also used this parameter as a measure for inflammation severity. For the DSS-treated group, the average colon length was $7.0 \pm 0.2 \mathrm{~cm}$ at day 14 , and even shorter for the 17 day time point $-6.5 \pm 0.2$ $\mathrm{cm}$. In contrast, the average colon length of the DSS + Quinacrine group was $8.4 \pm 0.3 \mathrm{~cm}$ for $10 \mathrm{mg} / \mathrm{kg}$ and $8.6 \pm 0.3 \mathrm{~cm}$ for $50 \mathrm{mg} / \mathrm{kg}$ dosages at 14 days, which is reaching the mean colon lengths in the water-alone group $(9.7 \pm 0.3)$ at the same time point. The average clinical disease index (CDI), which reflects overall health status of the animals based on observed weight loss, diarrhea and hemoccult (blood presence in the stool), clearly shows therapeutic effect of quinacrine on colitis progression average CDI of animals, treated with $50 \mathrm{mg} / \mathrm{kg}$ dose of quinacrine for 10 days after colitis onset, reduced more than twice, from $8.9 \pm 0.1$ to $4.0 \pm 0.8$. Similarly spleen volumes and white blood cell counts (reflecting systemic inflammation), and body weight recovered with quinacrine treatment (Table 1). Overall, these results are consistent with the notion that quinacrine suppresses DSS-induced colitis in time- and dose- dependent manner.

\section{Quinacrine suppresses colitis in oxazolone mouse model}

Although the DSS model of colitis is extremely useful in studying the therapeutic effects of small molecules against inflammation in the colon, a pitfall is that it is a chemically-induced model. Therefore, we have tested quinacrine in an alternative model - oxazolone model of colitis. We have followed Wirtz et al. protocol [27] with some modifications. While the first part of the animals were sacrificed in 5 days after oxazolone administrations (Oxazolone 5/5 groups), an additional dose of oxazolone was administered on day 5 to the second cohort of animals, which were also sacrificed in 5 days after the last oxazolone administration (groups Oxazolone 5/10). Similarly to DSS model, quinacrine was also given to mice ad libitum at the two doses of $50 \mathrm{mg}$ / $\mathrm{kg}$ and $10 \mathrm{mg} / \mathrm{kg}$ equivalent in the water $8 \mathrm{~h}$ after an intrarectal exposure to oxazolone and continued to the sacrifice time point. Mice that did not receive any quinacrine treatment developed moderate colitis by experimental 
Table 2: Gross characteristics of treated groups in Oxazolone model.

\begin{tabular}{|l|l|l|l|l|}
\hline Treatment & Weight change, $\mathbf{g}$ & $\begin{array}{l}\text { Colon Length, } \\
\mathbf{c m}\end{array}$ & CDI & Spleen, mm \\
\hline Water (5 days) & $0.5 \pm 0.1$ & $8.9 \pm 0.8$ & $0.2 \pm 0.2$ & $141.5 \pm 16.1$ \\
\hline Water (10 days) & $1.6 \pm 0.3$ & $9.7 \pm 0.3$ & $0.3 \pm 0.1$ & $101.5 \pm 6.3$ \\
\hline Oxozolon 5/5 & $-1.7 \pm 1.44$ & $7.5 \pm 0.2$ & $8.1 \pm 0.6$ & $253.2 \pm 19.3$ \\
\hline Oxozolon 5/10 & $-2.1 \pm 1.0$ & $7.7 \pm 0.8$ & $6.7 \pm 1.3$ & $192.1 \pm 20.7$ \\
\hline Oxazolon 5/5+10 mg/kg of Quinacrine & $1.41 \pm 0.3$ & $8.3 \pm 0.3$ & $1.71 \pm 0.8$ & $139.8 \pm 10.9$ \\
\hline Oxazolon 5/5+50 mg/kg of Quinacrine & $-0.5 \pm 0.8$ & $9.4 \pm 0.4$ & $2.9 \pm 1.0$ & $146.7 \pm 13.2$ \\
\hline Oxazolon 5/10+10 mg/kg of Quinacrine & $0.1 \pm 0.4$ & $8.5 \pm 0.3$ & $2.0 \pm 0.7$ & $175.4 \pm 25.8$ \\
\hline Oxazolon 5/10+50 mg/kg of Quinacrine & $-0.5 \pm 0.2$ & $9.9 \pm 0.3$ & $1.0 \pm 0.6$ & $105.9 \pm 10.2$ \\
\hline
\end{tabular}

Values are group averages \pm SE. Values are significantly different from corresponding Oxazolone only and Water groups.

day 10 with average inflammation score of $20.8 \pm 3.4$ (group Oxazolone 5/5), which progressed to a more severe state by experimental day 15 as indicated by average inflammation score of $28.5 \pm 5.6$ (group Oxazolone 5/10) (Figure 4A). In contrast, quinacrine drastically reduces severity of colitis in treated mice, resulting in reduction of inflammation scores to $5.4 \pm 1.6$ and $2.7 \pm 0.7$ for 50 $\mathrm{mg} / \mathrm{kg}$ dose in Oxazolone $5 / 5$ and Oxazolone 5/10 groups, correspondingly. The lower $10 \mathrm{mg} / \mathrm{kg}$ dose of quinacrine was also very effective for short term experimental group Oxazolone $5 / 5$, reducing inflammation scores to $5.3 \pm 1.7$, and less, but still effective, in the long term run $-8.1 \pm$ 1.5 for $10 \mathrm{mg} / \mathrm{kg}$ Oxazolone 5/10 groups. The substantial suppression of colitis in quinacrine treated mice was also reflected in all major parameters including colon length, weight change during the experiment, spleen volume and CDI (summarized in Table 2). For example, the CDI for quinacrine treated mice was almost 7 times lower for the dose of $50 \mathrm{mg} / \mathrm{kg}$, and 4 times lower for the dose of 10 $\mathrm{mg} / \mathrm{kg}$ for the Oxazolone $5 / 10$ groups.

Overall, treatment of mice with quinacrine in oxazolone model of colitis leads to suppression of colitis in both time-and dose dependent manner, similarly to DSS model.

\section{Markers of inflammation and inflammatory stress are reduced in quinacrine-treated mice}

To further assess the impact of quinacrine on inflammatory markers in vivo, we examined Cox2 , iNOS, and p53 expression in the colon of mice. Immunohistochemical staining was accomplished by rocking slides using the Antibody Amplifier ${ }^{\mathrm{TM}}$ (ProHisto, LLC) to ensure even, consistent, sensitive and reproducible staining. Figure 2B-2D show quantification of each endpoint for DSS model, and 3B-D - for oxazolone model. Overall, Cox-2 (Figures 2B, 4B), iNOS (Figures
2C, 4C), and p53 (Figures 2D, 4D) levels were elevated in both models' mice, with most staining appearing in the inflammatory cells. Cox-2 and iNOS staining were statistically significantly reduced in the quinacrine-treated mice; there was also a trend to decreasing p53 levels. Figure 5 shows representative sections of each endpoint as indicated. Such results reflect a reduction in the number of inflammatory cells (that otherwise are expressing these inflammatory markers), and complement our H\&E histopathology results.

\section{DISCUSSION}

UC is a painful disease and the complications of increased risk of colorectal cancer only add to the distress. Other than surgery, treatment available now can only alleviate the symptoms, giving temporary relief, but cannot cure the disease. Our search for a novel treatment for this disease led us to quinacrine; widely used as antimalarial and anti-protozoal drug. Since its discovery for use as an anti-parasitic, multiple studies have identified a putative anti-inflammatory mechanism for quinacrine [12, $13,28]$. With colon inflammation as a hallmark of UC, we hypothesized that quinacrine can suppress colitis in a mouse model of UC. Results we report here are consistent with this hypothesis.

We present that quinacrine suppresses the induction of iNOS in vitro (Figure 1), and iNOS, Cox-2 and p53 in vivo in two independent mouse models of colitis (Figures 2 and 3). Others have shown that quinacrine disrupts additional mediators of inflammation, including phospholipase A2, formation of prostaglandins, and the arachidonic acid cascade [29, 30]. Also, quinacrine inhibits NF- $\kappa B$, TNF $\alpha$, and IL-1 $\beta[14,31]$. Such results give insight into the potential mechanisms of quinacrine in suppressing UC. Importantly, anti-TNF therapy is a mainstream treatment for patients with moderate to severe inflammatory bowel disease [32]. There is also 
molecular evidence that iNOS, Cox-2 and p53 play a role in experimental colitis and human colitis [23, 3337]. Furthermore, IL-1 $\beta$ has been identified as a target for Inflammatory Bowel Disease treatment in multiple studies [38-40]. Mechanistically, IL-1 $\beta$ promotes innate immune pathology in intestinal inflammation by augmenting the recruitment of granulocytes and the accumulation and activation of innate lymphoid cells [41]. Therefore, suppressing IL-1 $\beta$ signaling has anti-inflammatory consequences. Finally, NF-kB signaling in myeloid cell appears to be critical for the development of colitis and colon cancer associated with colitis [42, 43].

Failure to regulate inflammatory responses in the intestinal or colonic mucosa leads to an inappropriate, sustained, and injurious immunologic reaction. A key mechanism for immune suppression is apoptosis of overly aggressive inflammatory cells and defects in inflammatory cell apoptosis are likely to be critical in the pathogenesis of colitis [44, 45]. We present evidence that quinacrine also induces apoptosis in inflammatory cells. In this context, others have also shown a pro-apoptotic impact

A.

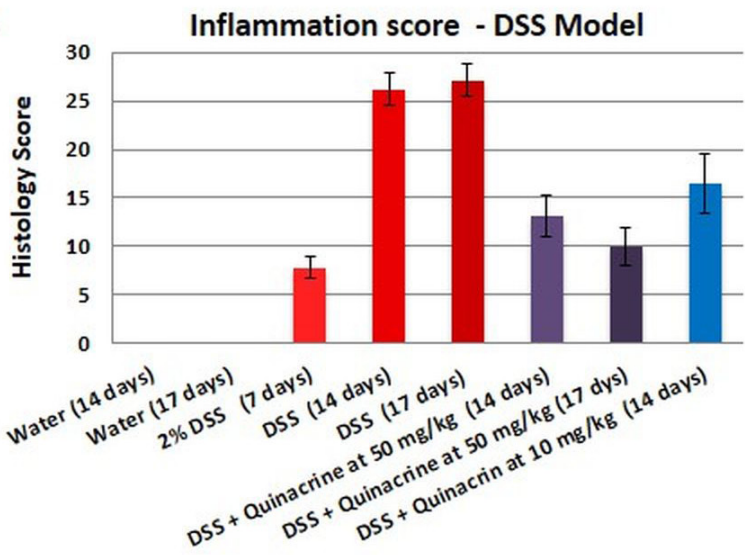

C.

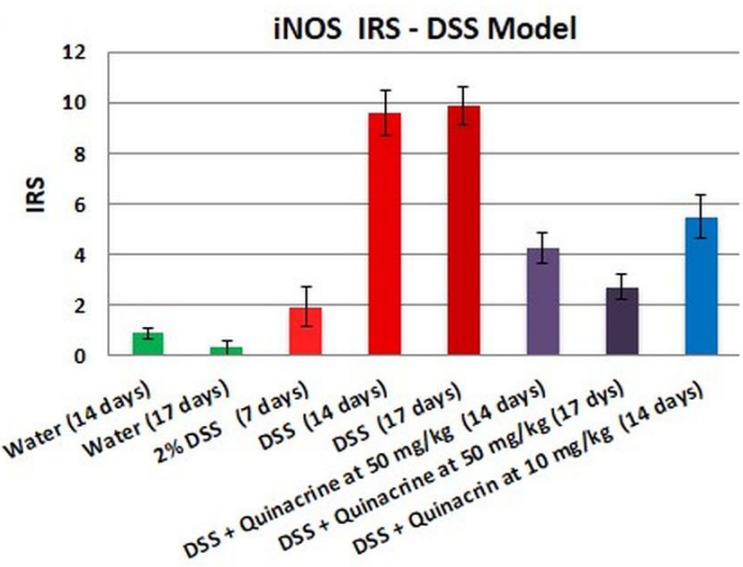

of quinacrine on other cell types, including colon cells, as an anti-cancer mechanism $[14,17]$. Such studies then identify an additional potential mechanism of quinacrine in the suppression of colon inflammation and the possible prevention of colon cancer.

Overall, quinacrine has a rich history as an antiprotozoal [46], anti-malarial [47], anti-rheumatic [48], anti-prion [49], anti-cancer [50], and an intrapleural sclerosing agent [50]. Consequently, it has potential or proven use against malaria [47], giardiasis [6], pneumothorax [51], Creutzfeldt-Jakob disease [52], cancer $[5,53]$, and in particular, female sterilization $[50$, 54]. Importantly, it also shows possible efficacy against rheumatoid arthritis [55] and lupus [56]. Because of this efficacy against arthritis and lupus (autoimmune diseases), and the ability of quinacrine to induce inflammatory cell apoptosis, it is not that surprising that quinacrine shows efficacy against another autoimmune disease: colitis. Future studies will determine efficacy in other models of colitis, and may eventually show efficacy against inflammatory bowel diseases in humans.

B.

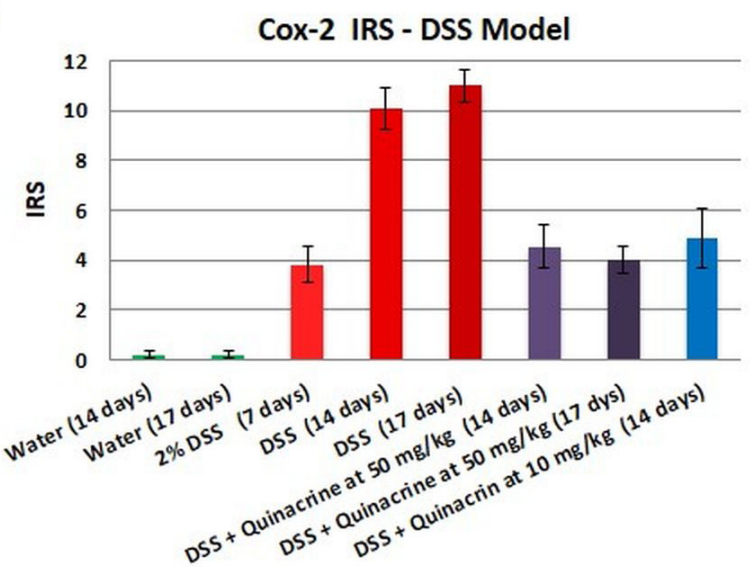

D.

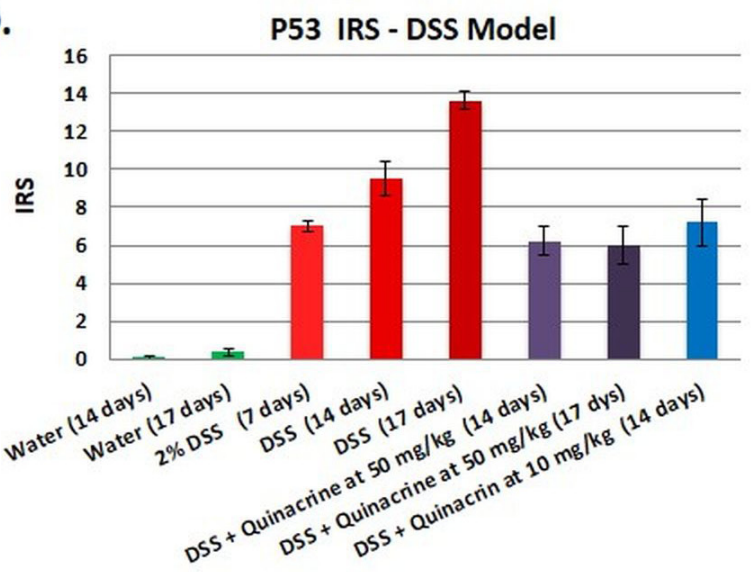

Figure 2: Effects of the quinacrine on the colon histology score, Cox-2 immunoreactivity score, iNOS immunoreactivity score, and p53 immunoreactivity score in the DSS model of colitis. Values represent the average scores for each group $(N=10$ 17 per group). All values are statistically significantly different $(p<0.05)$ from the other groups. 


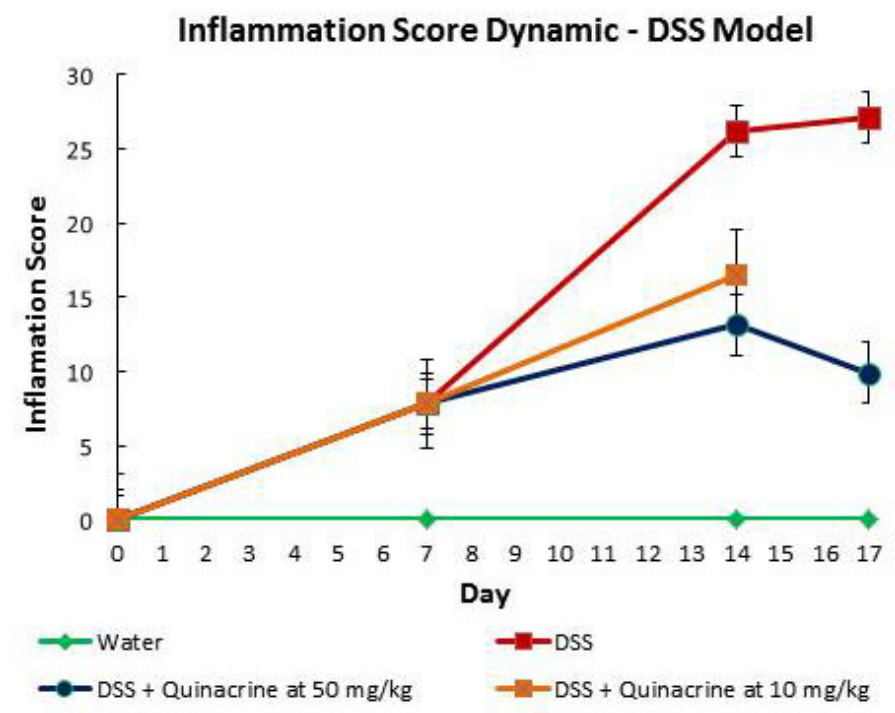

Figure 3: Dynamic of inflammatory score in DSS model of colitis.

A.

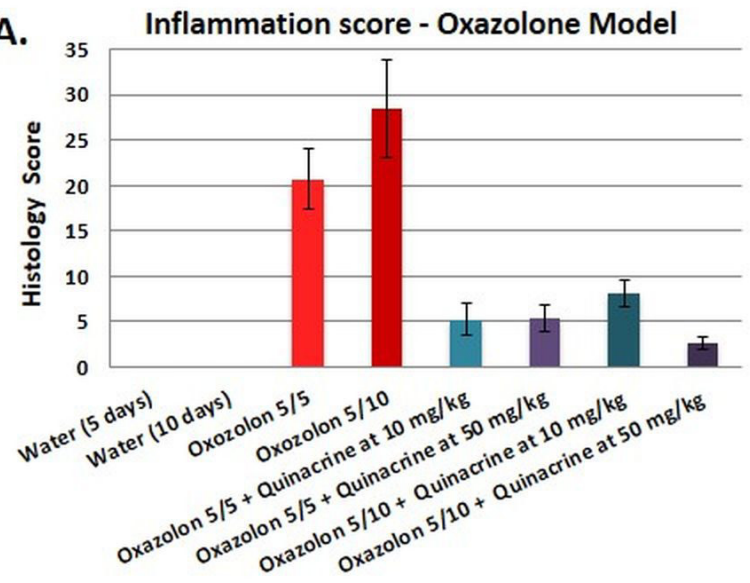

C.

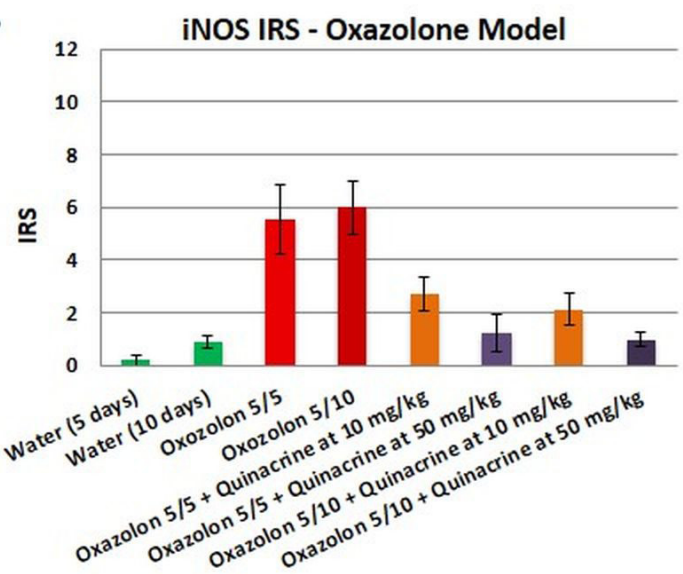

B.

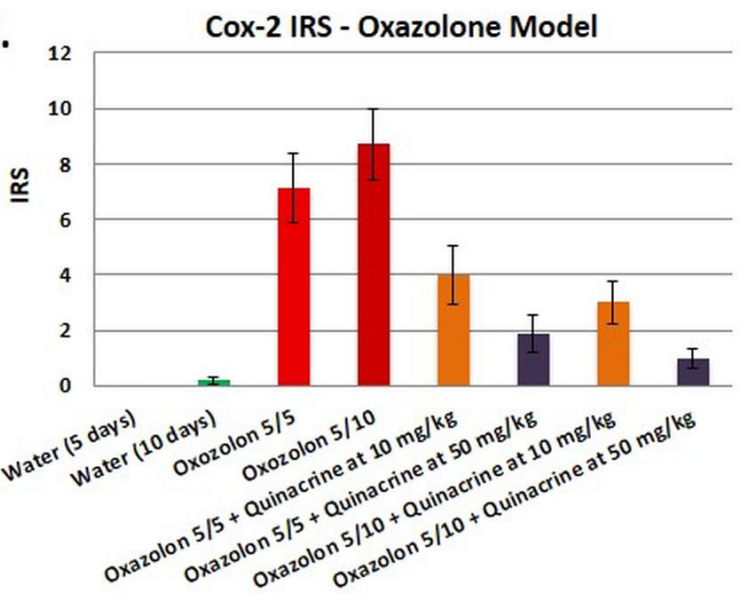

D.

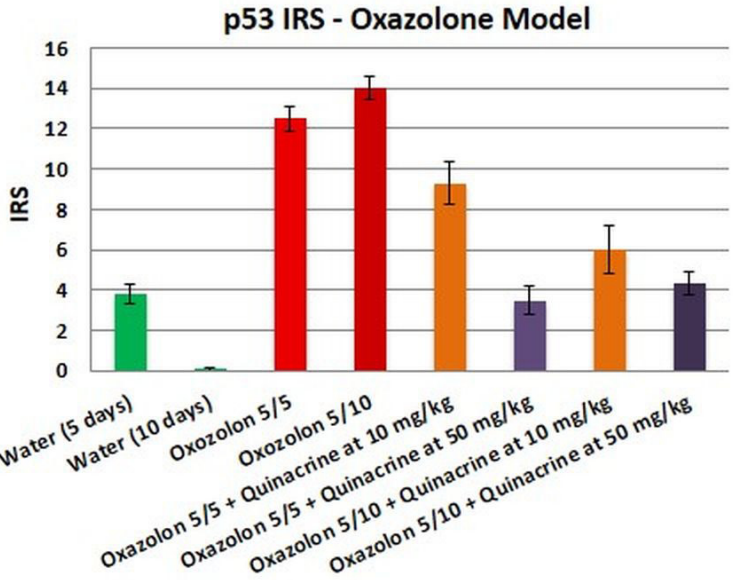

Figure 4: Effects of the quinacrine on the colon histology score, Cox-2 immunoreactivity score, iNOS immunoreactivity score, and p53 immunoreactivity score in oxazolone model of colitis. Values represent the average scores for each group $(N=$ $6-8$ per group). All values are statistically significantly different $(p<0.05)$ from the other groups. 


\section{MATERIALS AND METHODS}

\section{Chemicals and reagents}

Quinacrine dihydrochloride and oxazolone were obtained from Sigma. Dextran sulfate sodium (molecular weight, 36,000-50,000) was purchased from MP Biomedicals.

\section{Cell lines}

ANA-1 murine macrophage cells and TK6 human lymphoblastoid cells were maintained in Dulbecco's modified Eagle's media (Hyclone, Logan, UT) supplemented with $10 \%$ New Born Calf serum (NBCS) (Biofluids, Rockville, MD), $2 \mathrm{mM}$ glutamine (Biofluids), penicillin $(10 \mathrm{U} / \mathrm{ml})$ and streptomycin $(10$ $\mu \mathrm{g} / \mathrm{ml}$, Biofluids) in growing suspension culture at $37^{\circ} \mathrm{C}$ in a humidified $5 \% \mathrm{CO}_{2}$ atmosphere. Experiments with quinacrine were carried out by pre-incubating cells with indicated concentrations of quinacrine for specified times. Quinacrine was dissolved in DMEM medium $(0.1 \%$ NBCS) containing $1 \%$ DMSO. Following a wash step, cells were activated by exposure to $100 \mathrm{U} / \mathrm{ml}$ interferon (IFN)- $\gamma$ (R\&D Systems, Minneapolis, MN).

\section{Western blot analysis and antibodies}

Western blots were carried out as described previously [22, 57]. Antibodies used include: iNOS (Rabbit polyclonal, diluted 1 in 500, cat\#160862; Cayman Chemicals, Ann Arbor, MI) and GAPDH (Rabbit monoclonal, diluted 1 in 1000, cat\# 5174; Cell Signaling Technology, Danvers, MA). Horseradish peroxidaseconjugated anti-mouse and anti-rabbit secondary antibodies were purchased from Amersham Biosciences (Piscataway, NJ). Both secondary antibodies were diluted at $1: 2000$. All antibodies were diluted in $5 \%$ milk/PBST (0.1\% Tween 20 in PBS). The Western blot signal was detected by Pierce ECL Western Blotting Substrate (Thermo Scientific, Rockford, IL) and developed onto Hyperfilm (GE Healthcare Life Sciences, Pittsburgh, PA). Briefly, after treating blot with the chemiluminescent substrate (Pierce ECL) for a minute, the blot was exposed to the hyperfilm in the dark (Exposure time was optimized based on the band signal obtained) and the film was developed in an automatic x-ray film processor (Futura Classic E automatic x-ray film processor, Fisher Industry, Geneva, IL).

A.
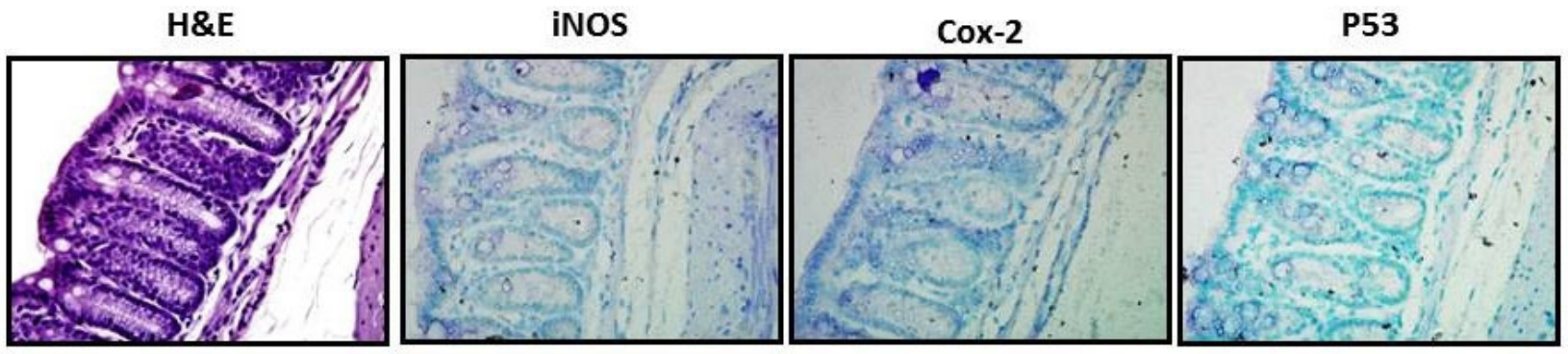

B.
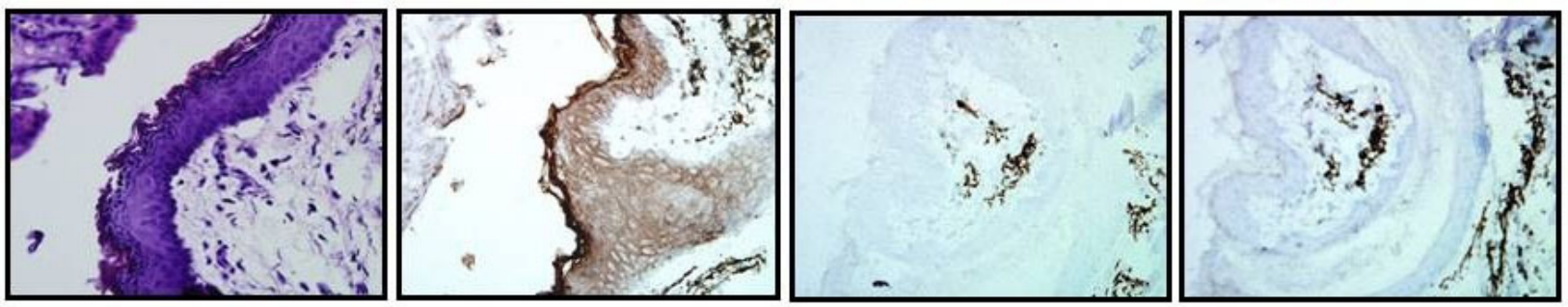

C.
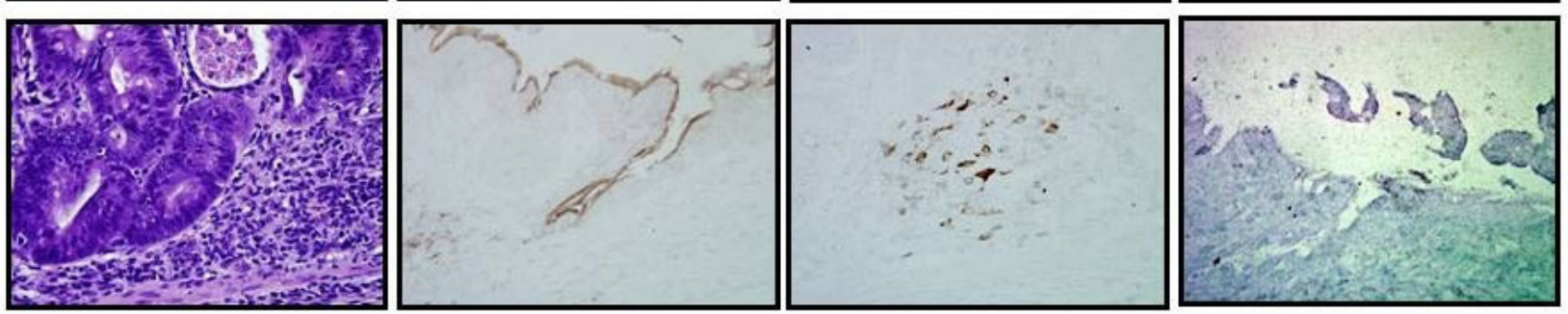

Figure 5: Representative histological and IHC sections from treated groups. A. Water; B. $2 \%$ DSS; C. $2 \%$ DSS $+50 \mathrm{mg} / \mathrm{kg}$ Quinacrine. 400x magnification. 


\section{Flow-cytometric TUNEL analysis}

TUNEL labeling was performed as we have done previously [25]. Briefly, TK6 cells were incubated in $0.1 \%$ NBCS supplemented RPMI-1640 media for $24 \mathrm{hrs}$. The media was changed and the cells were treated with vehicle $(1 \%$ DMSO in PBS) or quinacrine $(100 \mu \mathrm{g} / \mathrm{ml})$. Cells were harvested after $12 \mathrm{~h}$ of treatment and TUNEL assay was performed as described by vendor (Roche Diagnostics, $\mathrm{IN})$.

\section{Animals}

Male C57BL/ 6 mice, 8 weeks of age, weighing 20 to $25 \mathrm{~g}$ were obtained from The Jackson Laboratories. All mice were kept in dedicated and clean animal quarters and provided food and water. Care and use of animals was overseen by the Animal Resource Facility (ARF) of the University of South Carolina under the direction of a veterinarian. The ARF is fully accredited by the Association for Assessment and Accreditation of Laboratory Animal Care International, is registered with the U.S. Department of Agriculture (56-R-003) and has an active letter of Assurance of Compliance on file at the NIH. Animal Care and Use Committee (IACUC) of the University of South Carolina approved this study.

The dextran sulfate sodium (DSS) mouse model used here is similar to the one used previously by our lab [24]. Animals received either water or $2 \%$ DSS dissolved in water for 7 days. Seven days after the initial DSS treatment, and after confirming quinacrine does not interact directly with DSS, we initiated a daily regimen of $50 \mathrm{mg} / \mathrm{kg} /$ or $10 \mathrm{mg} / \mathrm{kg}$ of quinacrine dihydrocloride (Sigma) delivered in the drinking water containing 1\% DMSO (doses were calculated assuming that the average adult mouse consumes $5 \mathrm{ml}$ of water daily). DSS treatment continued in indicated groups. The doses of quinacrine were chosen based on the recommended dose in humans for treating systemic lupus erythematosis and giardiasis, which is $1.6 \mathrm{mg} / \mathrm{kg}$ (100 mg daily, with the assumption the average person weighs $60 \mathrm{~kg}$ ). The animal equivalent to $1.6 \mathrm{mg} / \mathrm{kg}$ in humans is $20 \mathrm{mg} / \mathrm{kg}$ [58]. Other previous studies have also used similar doses in mice by gavage [59]. Following 7 or 10 days of treatment with quinacrine, the mice were sacrificed and the colon was harvested for analysis.

For our oxazolone model of UC we used a modified protocol generally following the methods described by Wirtz et al. [27]. Briefly, on day 0, the skin of the mice was treated with either $150 \mu \mathrm{l}$ of oxazolone (Sigma, St Louis, MO) or $150 \mu$ l of vehicle control for pre-sensitization. The oxazolone presensitization solution is four parts acetone to one part olive oil containing 3\% (wt/vol) oxazolone. The vehicle control was four parts acetone to one part olive oil alone. After 5 days, mice were weighed, anesthetized and either $100 \mu \mathrm{l}$ oxazolone solution or $100 \mu \mathrm{l}$ vehicle control was given by rectal administration. The oxazolone solution was $1 \%$ oxazolone mixed into a $50 \%$ ethanol solution. The vehicle control was $50 \%$ ethanol solution alone. Mice were held in a vertical head down position for $60 \mathrm{~s}$ and then put back into their cages. For longterm oxazolone treatment group of mice, we performed an additional $1 \%$ oxazolone rectal administration in 5 days. Quinacrine treatment was started in $8 \mathrm{~h}$ after rectal oxazolone administration and continued daily. In 5 days after last $1 \%$ oxazolone administration, mice were euthanized and colons were processed for pathology and immunohistochemistry.

\section{Quantification of inflammation}

The harvested colon was washed in PBS, Swissrolled, fixed in formalin and embedded in paraffin. The sections were then stained with hematoxylin and eosin. The slides were examined by two individuals in a blind fashion and the histopathologic changes were recorded using the previously described scoring system [24]. Inflammation was scored based on the extent and severity of inflammation and also crypt damage of the colonic tissue. Histology score was determined by multiplying the range of involvement $(1-4)$ for each of these three histologic features by the percent area of involvement (0 $100 \%)$ as described previously [24].

\section{Immunohistochemical staining}

For immunohistochemical staining, serial sections of mouse colon tissues (processed as described above) were incubated with antibodies against p53 (Rabbit polyclonal, cat\# 31333, diluted 1:1000; Abcam, Cambridge, MA), cyclooxygenase-2 (Cox-2) (Rabbit polyclonal, cat\# 160126; diluted 1:5000; Cayman Chemical, Ann Arbor, MI) or inducible nitric oxide synthase (iNOS) (Rabbit Polyclonal, cat\# 160862, diluted 1:3500; Cayman Chemical, Ann Arbor, MI). To ensure even staining and reproducible results, sections were incubated by slow rocking overnight in primary antibodies $\left(4^{\circ} \mathrm{C}\right)$ using the Antibody Amplifier ${ }^{\mathrm{TM}}$ (ProHisto, LLC, Columbia, SC). Following incubation with primary antibody, sections were processed with EnVision+ System-HRP kits (DakoCytomation, Carpinteria, CA) according to the kit protocol. The chromogen was diaminobenzidene and sections were counter stained with $1 \%$ methyl green. The negative control was carried out without primary antibody incubation. 


\section{Quantification of immunohistochemistry}

Immunohistochemistry was quantified as we described previously [60], with a slight modification. The intensity of the staining was evaluated independently by two blinded investigators (A.C. and E.W.). For each tissue section, the percentage of positive cells was scored on a scale of 0 to 5 for the percentage of tissue stained: 0 ( $0 \%$ positive cells), $1(<10 \%), 2$ ( $11 \%$ to $25 \%), 3$ ( $26 \%$ to $50 \%), 4(51 \%$ to $80 \%)$, or $5(>80 \%)$. Staining intensity was scored on a scale of 0 to 3: 0 - negative staining, 1 - weak staining, 2 - moderate staining, or 3 - strong staining. The two scores were multiplied resulting in an immunoreactivity score (IRS) value ranging from 0 to 15 .

\section{Quantification of clinical disease index (CDI).}

CDI was assessed as described previously [61]. Briefly, mice were observed bi-daily for clinical signs of disease attributed by weight loss, fecal hemoccult and diarrhea during all treatments and till the final day of experiment. Ranking for the weight loss was based on the following scale: $0=0-5 \%$ weight loss; $1=6-10 \%$ weight loss; $2=11-15 \%$ weight loss; $3=16-20 \%$ weight loss; and $4=>20 \%$ weight loss. The appearance of diarrhea was scored as: $0=$ well-formed pellets, $2=$ pasty and semiformed stools that do not adhere to the anus, $4=$ liquid stools that adhere to the anus. Appearance of blood in the stools was assessed using a hemoccult kit (Beckman Coutler) and scored as: $0=$ no blood, $2=$ positive hemoccult, $4=$ gross bleeding. The clinical score was then determined by totaling the weight loss, hemoccult, and diarrhea scores with the highest score being twelve.

\section{Statistical analysis}

With inflammation as an end point, a $\chi 2$ contingency table analysis was done on the DSS and DSS + Quinacrine groups to determine if there was a statistically significant difference in their inflammation scores.

\section{ACKNOWLEDGMENTS}

This work was supported by National Institutes of Health Center for Colon Cancer Research, NIH grant 1R03CA171326 (LH), NCCAM, NIH 2 P01 AT00396106A1 (PN), and University of South Carolina Electronic Research Administration, USCeRA grant 11110-15-38752 (AC). We thank Tia Davis at the USC animal facility for the technical assistance in blood collection, and Dr. Donald Porter at Senex Biotechnology, Inc. for editorial help.

\section{CONFLICT OF INTEREST}

There is no conflict of interest.

\section{Editorial note}

This paper has been accepted based in part on peerreview conducted by another journal and the authors' response and revisions as well as expedited peer-review in Oncotarget.

\section{REFERENCES}

1. Desai D and Desai N. Colorectal cancer surveillance in inflammatory bowel disease: A critical analysis. World journal of gastrointestinal endoscopy. 2014; 6:541-548.

2. Ransohoff DF. Colon cancer in ulcerative colitis. Gastroenterology. 1988; 94:1089-1091.

3. Katzka I, Brody RS, Morris E and Katz S. Assessment of colorectal cancer risk in patients with ulcerative colitis: experience from a private practice. Gastroenterology. 1983; 85:22-29.

4. Ehsanian R, Van Waes C and Feller SM. Beyond DNA binding - a review of the potential mechanisms mediating quinacrine's therapeutic activities in parasitic infections, inflammation, and cancers. Cell Commun Signal. 2011; $9: 13$.

5. Gurova K. New hopes from old drugs: revisiting DNAbinding small molecules as anticancer agents. Future Oncol. 2009; 5:1685-1704.

6. Gardner TB and Hill DR. Treatment of giardiasis. Clin Microbiol Rev. 2001; 14:114-128.

7. Wozniacka A, Carter A and McCauliffe DP. Antimalarials in cutaneous lupus erythematosus: mechanisms of therapeutic benefit. Lupus. 2002; 11:71-81.

8. Macfarlane DE and Manzel L. Antagonism of immunostimulatory CpG-oligodeoxynucleotides by quinacrine, chloroquine, and structurally related compounds. J Immunol. 1998; 160:1122-1131.

9. Hofseth LJ and Ying L. Identifying and defusing weapons of mass inflammation in carcinogenesis. Biochim Biophys Acta. 2006; 1765:74-84.

10. Gurova KV, Hill JE, Guo C, Prokvolit A, Burdelya LG, Samoylova E, Khodyakova AV, Ganapathi R, Ganapathi M, Tararova ND, Bosykh D, Lvovskiy D, Webb TR, Stark GR and Gudkov AV. Small molecules that reactivate p53 in renal cell carcinoma reveal a NF-kappaB-dependent mechanism of p53 suppression in tumors. Proc Natl Acad Sci U S A. 2005; 102:17448-17453.

11. Gasparian AV, Burkhart CA, Purmal AA, Brodsky L, Pal M, Saranadasa M, Bosykh DA, Commane M, Guryanova OA, Pal S, Safina A, Sviridov S, Koman IE, et al. Curaxins: anticancer compounds that simultaneously suppress NFkappaB and activate p53 by targeting FACT. Sci Transl 
Med. 2011; 3:95ra74.

12. Al Moutaery AR and Tariq M. Effect of quinacrine, a phospholipase A2 inhibitor on stress and chemically induced gastroduodenal ulcers. Digestion. 1997; 58:129137.

13. Kara M, Yumrutas O, Atilgan R, Baspinar M, Sapmaz E and Kuloglu T. Expression changes of antioxidant, apoptotic, anti-apoptotic genes and miR-15b-34a-21-98 in over tissue by using erythromycin, quinacrine and tetracycline in nonsurgical sterilization. Mol Biol Rep. 2014.

14. Jani TS, DeVecchio J, Mazumdar T, Agyeman A and Houghton JA. Inhibition of NF-kappaB signaling by quinacrine is cytotoxic to human colon carcinoma cell lines and is synergistic in combination with tumor necrosis factor-related apoptosis-inducing ligand (TRAIL) or oxaliplatin. J Biol Chem. 2010; 285:19162-19172.

15. Dermawan JK, Gurova K, Pink J, Dowlati A, De S, Narla G, Sharma N and Stark GR. Quinacrine Overcomes Resistance to Erlotinib by Inhibiting FACT, NF-kappaB, and CellCycle Progression in Non-Small Cell Lung Cancer. Mol Cancer Ther. 2014; 13:2203-2214.

16. Fasanmade AA, Owuor ED, Ee RP, Qato D, Heller M and Kong AN. Quinacrine induces cytochrome c-dependent apoptotic signaling in human cervical carcinoma cells. Arch Pharm Res. 2001; 24:126-135.

17. Mohapatra P, Preet R, Das D, Satapathy SR, Choudhuri T, Wyatt MD and Kundu CN. Quinacrine-mediated autophagy and apoptosis in colon cancer cells is through a p53- and p21-dependent mechanism. Oncol Res. 2012; 20:81-91.

18. Preet R, Mohapatra P, Das D, Satapathy SR, Choudhuri T, Wyatt MD and Kundu CN. Lycopene synergistically enhances quinacrine action to inhibit Wnt-TCF signaling in breast cancer cells through APC. Carcinogenesis. 2013; 34:277-286.

19. Preet R, Mohapatra P, Mohanty S, Sahu SK, Choudhuri T, Wyatt MD and Kundu CN. Quinacrine has anticancer activity in breast cancer cells through inhibition of topoisomerase activity. Int J Cancer. 2012; 130:1660-1670.

20. Hofseth LJ, Hussain SP, Wogan GN and Harris CC. Nitric oxide in cancer and chemoprevention. Free Radical Biology and Medicine. 2003; 34:955-968.

21. Cui X, Jin Y, Hofseth AB, Pena E, Habiger J, Chumanevich A, Poudyal D, Nagarkatti M, Nagarkatti PS, Singh UP and Hofseth LJ. Resveratrol suppresses colitis and colon cancer associated with colitis. Cancer Prev Res. 2010; 3:549-559.

22. Jin Y, Kotakadi VS, Ying L, Hofseth AB, Cui X, Wood PA, Windust A, Matesic LE, Pena EA, Chiuzan C, Singh NP, Nagarkatti M, Nagarkatti PS, Wargovich MJ and Hofseth LJ. American ginseng suppresses inflammation and DNA damage associated with mouse colitis. Carcinogenesis. 2008; 29:2351-2359.

23. Jin $Y$, Hofseth $A B$, Cui $X$, Windust AJ, Poudyal D, Chumanevich AA, Matesic LE, Singh NP, Nagarkatti M, Nagarkatti PS and Hofseth LJ. American Ginseng
Suppresses Colitis through p53-Mediated Apoptosis of Inflammatory Cells. Cancer Prev Res. 2010; 3:339-347.

24. Chumanevich AA, Causey CP, Knuckley BA, Jones JE, Poudyal D, Chumanevich AP, Davis T, Matesic LE, Thompson PR and Hofseth LJ. Suppression of colitis in mice by Cl-amidine: a novel peptidylarginine deiminase inhibitor. Am. 2011; 300:G929-938.

25. Poudyal D, Cui X, Mai Le P, Davis T, Hofseth AB, Jin Y, Chumanevich AA, Wargovich MJ, Nagarkatti M, Nagarkatti PS, Windust A and Hofseth LJ. A limited role of p53 on the ability of a Hexane fraction of American ginseng to suppress mouse colitis. J Biomed Biotechnol. 2012; 2012:785739.(doi):10.1155/2012/785739.

26. Poudyal D, Cui X, Le P, Hofseth A, Windust A, Nagarkatti M, Nagarkatti P, Schetter A, Harris C and Hofseth L. A key role of microRNA-29b for the suppression of colon cancer cell migration by American Ginseng. PLoS One. 2013; 8:e75034.

27. Wirtz S, Neufert C, Weigmann B and Neurath MF. Chemically induced mouse models of intestinal inflammation. Nat Protoc. 2007; 2:541-546.

28. Illanes J, Dabancens A, Acuna O, Fuenzalida M, Guerrero A, Lopez C and Lemus D. Effects of betamethasone, sulindac and quinacrine drugs on the inflammatory neoangiogenesis response induced by polyurethane sponge implanted in mouse. Biol Res. 2002; 35:339-345.

29. Bondeson J and Sundler R. Antimalarial drugs inhibit phospholipase A2 activation and induction of interleukin lbeta and tumor necrosis factor alpha in macrophages: implications for their mode of action in rheumatoid arthritis. Gen Pharmacol. 1998; 30:357-366.

30. Horrobin DF, Manku MS, Karmazyn M, Ally AI, Morgan RO and Karmali RA. Quinacrine is a prostaglandin antagonist. Biochem Biophys Res Commun. 1977; 76:11881193.

31. Gorbachev AV, Gasparian AV, Gurova KV, Gudkov AV and Fairchild RL. Quinacrine inhibits the epidermal dendritic cell migration initiating $\mathrm{T}$ cell-mediated skin inflammation. Eur J Immunol. 2007; 37:2257-2267.

32. Chang JT and Lichtenstein GR. Drug insight: antagonists of tumor-necrosis factor-alpha in the treatment of inflammatory bowel disease. Nat Clin Pract Gastroenterol Hepatol. 2006; 3:220-228.

33. Dudhgaonkar SP, Tandan SK, Kumar D, Raviprakash V and Kataria M. Influence of simultaneous inhibition of cyclooxygenase-2 and inducible nitric oxide synthase in experimental colitis in rats. Inflammopharmacology. 2007; 15:188-195.

34. Hofseth LJ, Saito S, Hussain SP, Espey MG, Miranda KM, Araki Y, Jhappan C, Higashimoto Y, He P, Linke SP, Quezado MM, Zurer I, Rotter V, Wink DA, Appella E and Harris CC. Nitric oxide-induced cellular stress and p53 activation in chronic inflammation. Proc Natl Acad Sci U S A. $2003 ; 100: 143-148$. 
35. Kankuri E, Vaali K, Knowles RG, Lahde M, Korpela $\mathrm{R}$, Vapaatalo H and Moilanen E. Suppression of acute experimental colitis by a highly selective inducible nitricoxide synthase inhibitor, N-[3-(aminomethyl)benzyl] acetamidine. J Pharmacol Exp Ther. 2001; 298:1128-1132.

36. Spisni E, Valerii MC, De Fazio L, Cavazza E, Borsetti F, Sgromo A, Candela M, Centanni M, Rizello F and Strillacci A. Cyclooxygenase-2 silencing for the treatment of colitis: a combined in vivo strategy based on RNA interference and engineered Escherichia coli. Mol Ther. 2014.

37. Mukawa K, Fujii S, Tominaga K, Yoshitake N, Abe A, Kono T, Sekikawa A, Fukui H, Ichikawa K, Tomita $\mathrm{S}$, Imura J, Ono Y, Shinoda M, Hiraishi $\mathrm{H}$ and Fujimori $\mathrm{T}$. Inhibitory effects of the cyclooxygenase- 2 inhibitor, etodolac, on colitis-associated tumorigenesis in p53deficient mice treated with dextran sulfate sodium. Oncol Rep. 2008; 19:393-399.

38. Maeda S, Hsu LC, Liu H, Bankston LA, Iimura M, Kagnoff MF, Eckmann L and Karin M. Nod2 mutation in Crohn's disease potentiates NF-kappaB activity and IL-1beta processing. Science. 2005; 307:734-738.

39. Grottrup-Wolfers E, Moeller J, Karbach U, MullerLissner S and Endres S. Elevated cell-associated levels of interleukin 1beta and interleukin 6 in inflamed mucosa of inflammatory bowel disease. Eur J Clin Invest. 1996; 26:115-122.

40. Carvalho FA, Nalbantoglu I, Ortega-Fernandez S, Aitken JD, Su Y, Koren O, Walters WA, Knight R, Ley RE, VijayKumar M and Gewirtz AT. Interleukin-1beta (IL-1beta) promotes susceptibility of Toll-like receptor 5 (TLR5) deficient mice to colitis. Gut. 2012; 61:373-384.

41. Coccia M, Harrison OJ, Schiering C, Asquith MJ, Becher $\mathrm{B}$, Powrie F and Maloy KJ. IL-1beta mediates chronic intestinal inflammation by promoting the accumulation of IL-17A secreting innate lymphoid cells and CD4(+) Th17 cells. The Journal of experimental medicine. 2012; 209:1595-1609.

42. Greten FR, Eckmann L, Greten TF, Park JM, Li ZW, Egan LJ, Kagnoff MF and Karin M. IKKbeta links inflammation and tumorigenesis in a mouse model of colitis-associated cancer. Cell. 2004; 118:285-296.

43. Eckmann L, Nebelsiek T, Fingerle AA, Dann SM, Mages J, Lang R, Robine S, Kagnoff MF, Schmid RM, Karin M, Arkan MC and Greten FR. Opposing functions of IKKbeta during acute and chronic intestinal inflammation. Proc Natl Acad Sci U S A. 2008; 105:15058-15063.

44. Sartor RB. Mechanisms of disease: pathogenesis of Crohn's disease and ulcerative colitis. Nat Clin Pract Gastroenterol Hepatol. 2006; 3:390-407.

45. Neuman MG. Immune dysfunction in inflammatory bowel disease. Transl Res. 2007; 149:173-186.

46. Chibale K, Haupt H, Kendrick H, Yardley V, Saravanamuthu A, Fairlamb $\mathrm{AH}$ and Croft SL. Antiprotozoal and cytotoxicity evaluation of sulfonamide and urea analogues of quinacrine. Bioorg Med Chem Lett. 2001; 11:2655-2657.

47. Duncan GG. Quinacrine hydrochloride (atabrine) as a malaria suppressive agent. Air Surg Bull. 1945; 2:413.

48. Wallace DJ. The use of quinacrine (Atabrine) in rheumatic diseases: a reexamination. Semin Arthritis Rheum. 1989; 18:282-296.

49. Ghaemmaghami S, Ahn M, Lessard P, Giles K, Legname G, DeArmond SJ and Prusiner SB. Continuous quinacrine treatment results in the formation of drug-resistant prions. PLoS Pathog. 2009; 5:e1000673.

50. Zipper J, Dabancens A, Guerrero A and Trujillo V. Quinacrine: sclerosing agent of the utero-tubal junction in women, with anticarcinogenic actions in transplanted tumors in mice. Int J Gynaecol Obstet. 1995; 51 Suppl 1:S47-55.

51. Dikensoy O and Light RW. Alternative widely available, inexpensive agents for pleurodesis. Curr Opin Pulm Med. $2005 ; 11: 340-344$.

52. Forloni G, Artuso V, Roiter I, Morbin M and Tagliavini F. Therapy in prion diseases. Curr Top Med Chem. 2013; 13:2465-2476.

53. Gallant JN, Allen JE, Smith CD, Dicker DT, Wang W, Dolloff NG, Navaraj A and El-Deiry WS. Quinacrine synergizes with 5-fluorouracil and other therapies in colorectal cancer. Cancer. 2011; 12:239-251.

54. Sokal DC, Hieu do T, Loan ND, Hubacher D, Nanda $\mathrm{K}$, Weiner $\mathrm{DH}$ and Vach TH. Safety of quinacrine contraceptive pellets: results from 10-year follow-up in Vietnam. Contraception. 2008; 78:66-72.

55. Engeset A. Treatment of rheumatoid arthritis with quinacrine and chloroquine. Acta Rheumatol Scand. 1958; 4:28-39.

56. Toubi E, Kessel A, Rosner I, Rozenbaum M, Paran D and Shoenfeld Y. The reduction of serum B-lymphocyte activating factor levels following quinacrine add-on therapy in systemic lupus erythematosus. Scand J Immunol. 2006; 63:299-303.

57. Ying L, Marino J, Hussain SP, Khan MA, You S, Hofseth AB, Trivers GE, Dixon DA, Harris CC and Hofseth LJ. Chronic inflammation promotes retinoblastoma protein hyperphosphorylation and E2F1 activation. Cancer Res. 2005; 65:9132-9136.

58. Reagan-Shaw S, Nihal M and Ahmad N. Dose translation from animal to human studies revisited. Faseb J. 2007; 17:17.

59. Bian J, Kang HE and Telling GC. Quinacrine promotes replication and conformational mutation of chronic wasting disease prions. Proc Natl Acad Sci U S A. 2014; 111:60286033.

60. Cui X, Jin Y, Hofseth AB, Pena E, Habiger J, Chumanevich A, Poudyal D, Nagarkatti M, Nagarkatti PS, Singh UP and Hofseth LJ. Resveratrol suppresses colitis and colon cancer 
associated with colitis. Cancer Prev Res (Phila). 2010; 3:549-559.

61. Saxena A, Chumanevich A, Fletcher E, Larsen B, Lattwein K, Kaur K and Fayad R. Adiponectin deficiency: Role in chronic inflammation induced colon cancer. Biochimica et biophysica acta. 2012; 1822:527-536. 